\title{
The Impact of Country of Brand Image on Symbolic Value of Luxury Brands
}

\section{Qi Qiu}

Department of Marketing, College of Business Administration, Capital University of Economics and Business, China.

\section{Yonggui Wang}

Department of Marketing, School of Business, University of International Business and Economics, China.

\section{James Richard}

School of Marketing \& International Business, Victoria University of Wellington, New Zealand

\section{Xiaoyan Wang}

Department of Marketing, City University of Hong Kong, Hong Kong

\begin{abstract}
This research explores the different effects of country of brand (COB) image on symbolic value of luxury brands. Based on two empirical studies of symbolic value of sunglasses and sunscreen cream, we find that COB image has significant positive impacts on prestige value, social self-expressive value and inner self-expressive value while $\mathrm{COB}$ cues influence uniqueness value negatively. This research demonstrates that the effect of COB image on social self-expressive value and inner self-expressive value of luxury brands will be greater when subjects are promotion-primed rather than prevention-primed. In addition, $\mathrm{COB}$ image affects symbolic value prominently when the brand is closely related to $\mathrm{COB}$.
\end{abstract}

Keywords: $\quad$ Symbolic Value, Country of Brand Image, Luxury Brands, Regulatory Focus 


\section{Introduction}

"Le superflu, chose très nécessaire."

Voltaire once bemoaned: "for almost 2000 years, people in poetry eloquently had been attacking luxury, but always loved luxury" (Voltaire, trans. 2006) in that "le superflu, chose très nécessaire" (luxury goods were superfluous but necessary) (Voltaire, 1771). Voltaire contended that the development of the luxury industry would effectively create jobs, and luxury behavior was one of effective ways of allocating wealth from the rich to the poor. However, luxury consumption not only boosts the economy but also consoles. There is consensus that luxury brands are important carriers of symbolic value. Holman (1980) suggested that products that were different in economic strength could effectively deliver symbolic value of consumer goods. That is, only some consumers can buy such goods, while others cannot. On the basis of a comprehensive literature review of symbolic value from 16 top marketing journals in the last 30 years, we also discovered that luxury was an important symbolic value carrier. For example, many luxury brands are considered a status symbol (Phau \& Prendergast, 1998). Symbol value of a brand is mainly for shaping, developing and delivering consumer self-concept (Kleine, Kleine, Kernan, 1993; Belk, 1995; Fournier, 1998; Fischer, 2000; Hogg, Cox, Keeling, 2000; Voase, 2002; Schau \& Russell, 2005). Since self-concept is so abstract, there arises a need to express self in concrete ways. For example, consumers could define social roles by making use of symbolic value embedded in products or service (Leigh \& Gabel, 1992). Symbolic consumption is undoubtedly one of the shortcuts for people in modern society to express and maintain themselves. Together, these research streams suggest that symbolic value is significant motivation for consumers to purchase luxury goods.

It is worth noting that country of brand (COB) image is one of the important driving forces of consumer perceived value. Specifically, although consensus on the effect of country of origin on perceived quality seems to have emerged (Chao, 1993; Erickson, Johansson, \& Chao, 1984; Han \& Terpstra, 1988), COB image not only affected consumers from the perspective of cognitive function, but from the perspective of symbolic and emotional implications (Hong \& Wyer, 1989). Additionally, the study demonstrated that country of origin effect functioned more significantly in luxury consumption than in necessities consumption (Piron, 2000). The research also suggested that $\mathrm{COB}$ image stimulated perceived value of luxury brands more effectively than country of manufacture (COM) image (Phau \& Prendergast, 2000).

However, we still know very little about the relationship between COB image and symbolic value of luxury brands. The current study focuses on the effect of COB image on perceived quality and purchase intention (Häubl \& Elrod, 1999; Essoussi \& Merunka, 2007). Importantly, Chinese luxury consumers are generally so young that they have lower brand familiarity than consumers in developed countries (McKinsey, 2011). Moreover, it is found that country of origin effect is more significant in the context of brand unfamiliarity (Gerstner, 1985; Johansson, Douglas, Nonaka, 1985). Therefore, this study attempts to explore whether there is significant interaction between $\mathrm{COB}$ image and symbolic value of luxury brands for Chinese luxury 
consumers, and whether the effects of those factors vary with regulatory focus and strength of brand-country association.

The current research contributes to the body of extant literature by demonstrating that favorable $\mathrm{COB}$ image will encourage more prestige value, social self-expressive value, inner self-expressive value, but less uniqueness value; the interaction between $\mathrm{COB}$ image and self-expressive value (including social self-expressive value and inner self-expressive value) will be reinforced for consumers with promotion focus; $\mathrm{COB}$ effect functions significantly in luxury symbolic consumption when brands are strongly linked to the COB.

The following section presents overviews regarding symbolic value and $\mathrm{COB}$. Next, this study discusses theoretical frameworks and the link between COB image and symbolic value. Subsequently, the paper explains the methodology used in the study and provides its empirical results. This study concludes by offering practical and theoretical implications.

\section{Literature Review}

\section{Symbolic Value}

The modern era of research on symbolic value seems to have commenced in 1950 with Haire's (1950) publication. Such issues have been investigated in the literature for the past several decades, during which time topics focused on the following aspects: (1) definition. There are basically two views on how to define symbolic value. Some researchers contend that symbolic value is subjective value perceived by consumers, more specifically, consumers perceive symbolic value (e.g. prestige and self-expression) by brand consumption. Conversely, others insisted that symbolic value is objective value except functional value (Leibenstein, 1950; Keller, 1993); (2) dimensions. The initial research on symbolic value mainly focused on the interpersonal influence-oriented value, such as prestige value and social selfexpressive value (e.g. Vigneron \& Johnson, 1999, 2004; Rio, Vazquez, Iglesias, 2001); However, much research also suggests that consumers perceive personal influence-oriented value such as self-expressive value and uniqueness value (Rio et al. 2001; Bauer et al., 2004); (3) Rationales. The researchers primarily discuss and explain inherent mechanisms of symbolic consumption using the theory of symbolic interactionism and ritual behavior, among which symbolic interactionism is the mainstream; (4) Antecedents. Previous research on symbolic value before 2000 mainly explored the conceptualization and formation mechanisms of symbolic value, of which there is a huge stream of researches on the motivation of symbolic consumption in the literature. While after 2000, the research began to focus on what factors have an effect on symbolic value from the perspective of consumption psychology, product / brand, culture, purchase context and social ecology. First, the psychological factors consist of a reference group (Childers \& Rao, 1992), consumer experience (Tsai, 2005) and ethnic identity (Maldonado \& Tansuhaj, 1999). Then, brand or product factors arerelated mainlyto product meanings (Wong \& Ahuvia, 1998), product scarcity (Heribert \& Verena, 2010), COB image (Piron, 2000) and brand prominence (Han, Nunes, Drèze, 2010). Next, some researches explored cultural influence on the symbolic value from national culture (Eng \& Bogaert, 2010), traditional values (Wong \& Ahuvia, 1998) and materialism (Richins, 1994). Finally, 
the effect of purchase contexts (public vs. private) (Bearden \& Etzel, 1982) and social ecological factors (e.g. mating motives) (Sundie et al., 2011) on symbolic value are also discussed.

\section{Country of Brand}

This research demonstrates that differences in country image will affect consumers' attitudestoward brands, thereby affecting consumers' purchase intention (Leonidas et al., 1999; Laroche et al., 2005). In other words, when people from one country tend to have the same insights about another country, this stereotype may affect product evaluation from the country (Billey \& Nes, 1982). Once the country is linked to a specific product, the country of origin is formed. Country of Origin (COO) is where products or brands will be perceived as coming from (Saeed, 1994), but it is probably inconsistent with the location of the firm's headquarters. With development of global division of labor as well as cooperation, country of origin image is different from objective and subjective perspective due to the difference in cognition of COO.

COO may have a significant influence on consumption. Phau and Prendergast (2000) contended that COO study fell into three distinct phases as follows: first, $\mathrm{COO}$ is used as single cue to affect product evaluation. In the seminal study, Dichter (1962) investigated the COO effect. Schooler's (1965) subsequent research concluded that stereotypes did exist when consumers evaluate products from different countries, which is related to consumers' general cognition in the context of COO. The research indicated that COO effects generally existed in various products (Reierson, 1966). Although single cue research dominated the initial phase of COO research, such research was criticized for exaggerating the COO effect (Phau \& Prendergast, 2000). Then, subsequent research used multi-cues to improve COO research (Gaedeke, 1973). There is a huge stream of researches on COO effect in the literature, as follows: demographic factors (e.g. age, gender, education, race, color etc.) (Schooler, 1971; Dornoff, 1974); product type (Lillis \& Naragana, 1974); price (Papadopoulas, Heslop, \& Beracs, 1990); level of economic development and country reputation (Khachaturian \& Morganosky, 1990); ethnocentrism (Han, 1988; Hong \& Wyer, 1989; Papadopoulas, Heslop, \& Beracs, 1990); product complexity; retailer reputation (Khachaturian \& Morganosky, 1990) ; COO hierarchy effects (Tse \& Gorn, 1993; Thakor \& Kohli, 1996); brand familarity (Lee \& Ganesh, 1999); Finally, COO is decomposed into country of manufacturing (COM), country of assembly (COA), country of design (COD), and country of brand (COB). Before the establishment of a global division of labor, $\mathrm{COO}$ was quite simple, that is, $\mathrm{COM}$ was usually equated with $\mathrm{COB}, \mathrm{COM}$, or COD. With the development of globalization, single-origin products in international markets are scarce except for a few specific categories (such as agricultural products or mineral resources). Hybrid products that are manufactured, branded and assembled in different countries gradually dominate the market. Thus, COO becomes a multi-dimensional construct, including COM, COA, COD, and COB. (1) COM. Saeed (1994) suggested that COM was the last location where the product was manufactured; (2) COA, the country where the product was assembled (Chao \& Rajendran, 1993); (3) COD, the country where R \& D located (Chao \& Rajendran, 1993; Ahmed \& d' Astous, 1996). (4) COB. With reference to definition of COB, there are two schools of thought. Some researchers argue that $\mathrm{COB}$ is the location of enterprises which design and have name-brands as core assets, or the country underlying in brands (Han \& Terstra, 1988), while others insist that COB is the 
country where target customers perceive that the brand originates (Thakor \&Kohli, 1996). Given the dynamic changes in the brand ownership and market information asymmetry, this study uses the latter definition of COB.

It is worth noting that how to measure $\mathrm{COO}$ image has always been of concern. Nagashima (1977) measured COO with price and value, service and engineering, advertising and reputation, design and style, and consumers' demographic features; Narayana (1981) proposed a scale of COO including quality, cognition, reputation, product type, popularity, and functional value; Han (1989) also proposed to measure COO using technical level, prestige, craftsmanship, price, and practicality; Parameswaran and Pisharodi (1994) presented forty research indicators based on general national characteristics, general product attributes and specific product attributes; Agarwal and Sikri (1996) believed that technology, prestige, and price were critical factors for measuring COO image; Chattalas, Kramer, and Takada (2008) contended that competence and warmth were two dimensions of COO image from the perspective of consumer perception. This different understanding of the $\mathrm{COO}$ concept has led to inconsistencies in measurement indicators in current research.

$\mathrm{COO}$ is one of the driving forces of perception value and purchase intent. In particular, when consumers are not familiar with foreign products, $\mathrm{COO}$ will become an important external cue for product evaluation (e.g. Gerstner, 1985). Ahmed, d'Astous, and Eljabri (2002) suggested that the degree of COO industrialization had a positive impact on the perceived quality, which was moderated by involvement, technical complexity, and technological innovation; Lin and Kao (2004) proposed that $\mathrm{COO}$ had an effect on brand equity by consumer perception and purchasing behavior; Essoussi and Merunka (2007) provided evidence that COD and COM had a positive impact on perceived quality by brand image; COM image, congruity between $\mathrm{COM}$ and $\mathrm{COB}$, as well as congruity between $\mathrm{COM}$ and product have a positive impact on perceived quality. Prior research has indicated that $\mathrm{COB}$ image had an indirect effect on consumer purchase intention by perceived quality, which was moderated by product involvement. For example, Ahmed and Asrous (1995) claimed that COB image was one of the crucial external cues for assessing consumer perceived quality. Many researchers replicated the results in different product contexts that both COB and COM image would have an impact on product evaluation (Han \& Terpstra, 1998; Narasimhan, Subhash, Kiranjit, 2004). Furthermore, Ahmed and Asrous (1996) discovered that COB effect was more significant than COM effect in a high level of product involvement context. In addition, Chen (2004) found that early adopters tend to use COM image as the cue of product evaluation, while interim adopters and laggards would prefer $\mathrm{COB}$ image as the evaluation criteria.

\section{Theoretical Development}

On the basis of this review of relevant literature, symbolic value consists of interpersonal influence-oriented value and personal influence-oriented value. The former includes prestige value and social self-expressive value (e.g. Vigneron \& Johnson, 1999, 2004; Rio, Vazquez, Iglesias, 2001); and the latter involves selfexpressive value and uniqueness value (Rio et al. 2001; Bauer et al., 2004). The following discusses the relationship between $\mathrm{COB}$ image and symbolic value. 


\section{COB Image and Symbolic Value}

Generally, COB image is used to evaluate foreign products in three ways: 1) clues utilization. Consumers take $\mathrm{COB}$ as external cues for product evaluation (e.g. perceived quality) (Chao, 1993; Phau \& Prendergast, 2000); 2) halo effect and summary effect. The halo effect functions when consumers have less familiarity with products. More specifically, consumers would infer product attributes from the country image, which would ultimately affect brand attitude. On the contrary, summary effect would work if consumers have intimate knowledge of products, that is, consumers' belief in a specific product would affect country image, which would influence brand attitude directly (Erickson, Johansson, \& Chao, 1984; Han, 1989); 3) Supplementary information. COO image is used to fill the missing product information especially when consumers have insufficient information to make a decision (Hong \& Wyer, 1989). The mechanisms above are used to explain the interaction between COB image and perceived value. Although consensus on the effect of COB (Han \& Terpstra, 1998; Narasimhan, Subhash, \& Kiranjit, 2004) and more significant influence of COB than other dimensions (Thakor \& Kohli, 1996; Lim and O'Cass, 2001; Samiee Shimp, \& Sharma, 2005; Kinra, 2006; Martín \& Cerviño, 2011) emerged, the underlying psychological mechanisms of how COB influences consumers are somewhat unknown.

Unlike the previous research, this study intends to explore the relationship between $\mathrm{COB}$ image and the prestige value of symbolic value from the perspective of emotional mechanisms. It is worth noting that $\mathrm{COO}$ is not only a cognitive clue, but points even more tangibly to the consumer's emotional reaction. COO can embed sentiment connotation, status and ritual in a country image, which links products to country identity and self-esteem producing a strong emotional association. Therefore, COO image is often considered as an attribute of emotional expression, especially in developing countries (Verlegh \& Steenkamp, 1999; Batra et al., 2000). According to the consumption emotion theory, the dominant trait of human beings is that emotion is associated with the value system (Frijda, 1988). Consumption emotion is the psychological reaction obtained from product attributes and perceived value (Dube \& Menon, 2000). Positive emotional response can enhance the perception of the core values; conversely, negative emotions would reduce perceived core values.

COO embodies image properties that can be associated with symbolic value including social status and self-esteem (Botschen \& Hemettsberger, 1998; Askegaard \& Ger, 1998; Fournier, 1998). We propose that COB image is able to stimulate consumer association and emotional experience; therefore, consumers can project preferable COB image onto their own, which would highlight the individual's prestige value such as social status, wealth and respect. Together, these research streams suggest that $\mathrm{COB}$ image would have a positive impact on prestige value of the interpersonal symbolic value in accordance with consumer emotion theory. More formally,

H1: Consumers' perceived prestige value of purchasing luxury brands is greater when COB image is favorable.

Biel (1992) proposed that luxury brands provided a means whereby consumers could exercise self-expressivity, which includes both the inner self-expressive value and social self-expressive value (De Chernatony \& Riley, 1998). Consumers could deliver 
self-image by brand consumption. Prior research indicated that COB image featured "expression" or "image" attributes. According to this research, the former contained self-esteem needs, social needs and self-actualization needs (Mittal, Ratchford \& Prabhakar, 1990); whereas, the latter referred to consumer's inner self-image and social image delivered during the process of consumption (Lefko.-Hagius \& Mason, 1993). The research shows that people will be able to express themselves through consumption when they purchase products from a country (Nebenzahl, Jaffe, \& Usunier, 2003).

We expect that the $\mathrm{COB}$ with a developed economy, high standard of living, technologically advanced, highly educated, hard-working image can trigger positive associations. Consumers who purchase the brand from such a COB are more likely to enhance consumers' self-image and inform others of which group they belong to than those who purchase products from unfavorable COB. Moreover, consumers can absorb and transfer components of COB that coincide with their ideal self to the society, therefore establishing a self-image and obtaining social identity. We propose that $\mathrm{COB}$ image will have a favorable impact on social self-expressive value and inner self-expressive value. In sum, we have:

H2: Consumers' perceived social self-expressive value of purchasing luxury brands is greater when COB image is favorable.

H3: Consumers' perceived inner self expressive value of purchasing luxury brands is greater when COB image is favorable.

However, a favorable COB image may probably not be able to positively 'inspire' all the symbolic value. We would explain this inability with Contradictory Attitude Theory (CAT). In 1911, a Swiss psychiatrist Blueler discovered that both positive and negative evaluation could exist simultaneously towards the same object, when he analyzed early symptoms of patients with schizophrenia. Then Blueler advanced CAT. Otnes, Lowery and Shrum (1997) first introduced CAT to the field of consumer psychology, and similarly suggested that it was possible for consumers to simultaneously have a positive and negative perception and emotional experience towards the same marketing factors. As to luxury goods, there is a longstanding contradictory attitude for most people. On the one hand, people must morally despise luxury goods in that luxury is closely related to redundancy, and luxury consumers are always those who plunder the wealth of society; On the other hand, however, people seldom exclude themselves from enjoying luxury consumption (Reitzle, 2003). This is also consistent with Voltaire's views, who believed that people loved luxury while, at the same time, attacking luxury. According to CAT, if a favorable COB image has a positive impact on prestige value, social self-expressive value, and inner selfexpressive value,there may be a negative impact between such country image and another component of symbolic value.

From the COB perspective, country image means opinions that people from one country share about another (Bilkey \& Nes, 1982). Country image is formed by the co-creation of products, national characteristics, economic and political environment, history and traditions (Nagashima, 1970). Thus, to a certain extent, merits of country image could be a relatively common view, and a subjective perception of objects. In addition, we suggest that $\mathrm{COB}$ effects are also normative, that is, consumers will comply with the social and personal norms with regard to COB. For example, the 
research indicated that it was a way of supporting a country's economy to purchase domestic products (Shimp \& sharma, 1987). Consumers can even resist purchasing products from $\mathrm{COB}$ with inhumane regimes or those experiencing worldwide condemnation according to the product information.

However, the nature of $\mathrm{COB}$ mentioned above is likely to be inconsistent with uniqueness value of symbolic value. According to Ruvio, Shoham and Brencic (2008), uniqueness value consists of two dimensions: deviation from social norms and avoidance of similarities. That is, consumers who pursue uniqueness value will be very sensitive to the similarity and emphasis on doing something extraordinary (Snyder, 1992). Not surprisingly, such desire will be constrained by social norms (Snyder \& Fromkin, 1980). Thus, consumers' uniqueness needs will not totally violate social norms, but will deviate them. In such cases, the more favorable COB image is, the more consistent brands linked to such COB are with social norms. That is, such brands are likely to conform tothe values of most people, but are detrimental to consumers who seek uniqueness. Based on the above analysis, we propose that $\mathrm{COB}$ image will have a negative influence on uniqueness value of symbolic value, which is different from the three-way interaction between COB image vs. prestige value, $\mathrm{COB}$ image vs. social self-expressive value, and $\mathrm{COB}$ image vs. the inner selfexpressive value. Formally, we therefore predict the following:

H4: Consumers' perceived inner uniqueness value of purchasing luxury brands is less when COB image is favorable.

\section{Regulatory Focus}

Higgins (1998) proposed Regulatory Focus Theory (RFT), which suggested that, for the sake of different objectives, people would follow two principles to adjust their behavior: promotion focus and prevention focus. Some people who "focus on promotion" tend to pursue the positive outcomes (e.g. ideal, aspiration, accomplishment); conversely, others who follow the principle of prevention focus will seek the responsibility, for example, performing one's duties, capturing a sense of security, and avoiding losses. In other words, ideal and responsibility can inspire different regulatory focus systems: the former is linked to promotion focus, and the latter is associated with prevention focus.

More specifically, ideal is what people desire and hope, that is, what they like to do (e.g. traveling abroad, buying a big house); responsibility is what people ought to do (e.g. finish their work, pay taxes). Notably, there is significant difference between the two regulatory focus systems. Prior researches show that promotion-focused consumers pay more attention to abstract information, while prevention-focused consumers emphasize concrete information (Zhu \& Meyers-Levy, 2007). Compared with concrete functional value of brand, symbolic value of brand should be more abstract, uncovering the underlying psychological mechanism between consumers and brands. Therefore, we expect that regulatory focus is likely to moderate the relationship between $\mathrm{COB}$ image and symbolic value. We elaborate the interactions as follows:

Individual prestige is considered as respect and trust from groups on the individual level. From a sociological point of view, prestige is an ideal for people in different 
social classes, just like power and income, and therefore various expectations for prestige become one of the differences between social classes to some extent. According to RFT, under the guidance of promotion focus, people prefer to achieve the ideal. As we discussed above, given that a favorable COB image has a positive effect on prestige value, a favorable COB image can enhance the perception of 'the ideal'. In such a case, promotion-focused consumers are likely to more favorable toward the interaction between $\mathrm{COB}$ image and prestige value than preventionfocused consumers. Together, we propose that promotion-focused principles will inspire the relationship between COB image and prestige value. Formally, we predict the following:

H5: The effect of COB image on prestige value of luxury brands will be greater when subjects are promotion-primed than prevention-primed.

The effect of COB image on symbolic value embodies an emotional experience. According to Rogers' (1961) Self Congruence theory, the closer ideal self is to real self, the more positive the emotional experience people will have, and the happier people feel. The favorable COB image essentially delivers the message of ideal inner self and ideal social self. For example, French culture represents aesthetic sensitivity, delicacy, taste, pleasure, elegance, etc (Peabody, 1985). When consumers purchase French luxury brands, the association embedded in the French image will be projected onto consumers themselves, so that consumers also have beautiful Frenchrelatedassociations such as pleasure, elegance, etc. In such a case, we believe that better COB image can serve the function of shortening the distance between ideal self and real self, thus consumers will have a more positive emotional experience. In this way, consumers with positive emotion would generate an intense purchase intention for luxury brands from such a COB.

Previous studies on RFT indicated that promotion-focused consumers were more susceptible to emotional domination than prevention-focused consumers. For example, Higgins (1988) proposed that promotion-focused consumers would act on sentiment, preferring expressions of cheerfulness-dejection (e.g. joy, satisfaction); while prevention-focused consumers usually act rationally, preferring expressions of quiescence-agitation (e.g. relaxation, quiet, anxiety). Pham and Avnet (2004) also discovered that promotion-focused consumers were more sensitive to emotional cues than prevention-focused ones. Specifically, promotion-focused consumers rely more on emotion to make decisions, while prevention-focused consumers are dependent on rational information to make decisions. Therefore, we propose that moderating effect of regulatory focus functions between $\mathrm{COB}$ image and social self-expressive value. Compared with prevention-focused consumers, promotion-focused consumers are more likely to be influenced by favorable COB image, perceiving more social selfexpressive value. More formally,

H6: The effect of COB image on social self-expressive value of luxury brands will be greater when subjects are promotion-primed than prevention-primed.

H7: The effect of COB image on inner self-expressive value of luxury brands will be greater when subjects are promotion-primed than prevention-primed. 


\section{Strength of Brand-country Association}

Strength of brand-country association is the extent to which a brand is associated with COB image in consumers' minds, which is consumers' perception of brand (Haubl \& Elrod, 1999). Some brands are strongly associated with COB, while others lacksuch association. For example, some consumers believe that Prada is a typically Italian brand, rather than Fendi. According to Human Associative Memory (HAM) and Adaptive Network Model (ANM) theory, human memory consists of nodes and connecting links: nodes are embedded concepts or information; connecting links stand for the strength of connection between nodes. If one node is stimulated strongly to a certain extent, it will activate another node (van Osselaer \& Janiszewski, 2001). In terms of $\mathrm{COB}$ effect, $\mathrm{COB}$ and brands are considered as two types of nodes. When COB is linked to a brand, the effect of "attribute to brand" model occurs (Krishnan, 1996).

When a brand is strongly associated with $\mathrm{COB}$, whether the COB image is favorable or not can affect symbolic value of brands. Based on HAM and ANM theory, when the node of $\mathrm{COB}$ is stimulated to a certain extent, it will activate the node of brand image. Specifically, on the premise of awareness of COB, COB exposing in the mass media becomes the important basis for consumers' brand evaluation. If consumers believe that $\mathrm{COB}$ image is significantly positive, they tend to have a higher perception of brand prestige. Brucks, Zeithaml and Naylor (2000) claimed that brand prestige can typically convey the superiority of consumers' social class. Similarly, superiority of social class islinked to individual prestige. When COB is closely related to a brand, a favorable $\mathrm{COB}$ image will produce a higher degree of prestige value; conversely, when $\mathrm{COB}$ is not related to a brand, even a favorable $\mathrm{COB}$ image will fail to have a significant effect on prestige value. Therefore, we hypothesize that, everything else being equal, strength of brand-country association has a positive effect on the interaction between COB image and prestige value. Formally,

H8: The effect of $\mathrm{COB}$ image on prestige value of luxury brands will be greater with the increase in the strength of brand-country association.

COB image can help people improve self-expression by way of brand image. When there is higher strength of brand-country association, consumers are likely to express themselves by purchasing products from such a country (Nebenzahl, Jaffe, \& Usunier, 2003). Consumers prefer to select the brands that match self-concept in that they believe consumption of such brands is a way of self-expression (Belk, 1988). In addition, consumers intend to build, maintain and deliver an abstract self-concept through brand consumption, in order to obtain social identity (Schau \& Gilly, 2003). Since the research indicated that both social self-expressive value and inner selfexpressive value are significant motives for luxury consumption (Vigneron \& Johnson, 1999, 2004), favorable COB image will be helpful for luxury consumption.

After Stayman and Deshpande's (1989) study, Forehand, Deshpande, and Americus (2002) found that consumers were usually attracted by brands, which were associated with their social identity. Therefore, when $\mathrm{COB}$ image is strongly associated with brand, COB image will be used to convey social self because a favorable COB image helps consumers to retain social identity. Hence, we propose that strength of brandcountry association is likely to moderate the relationship between COB image and 
social self-expressive value. Similarly, the effect of moderation may occur as to the interaction between $\mathrm{COB}$ image and inner self-expressive value. More formally,

H9: The effect of COB image on social self-expressive value of luxury brands will be greater with the increase in the strength of brandcountry association.

H10: The effect of $\mathrm{COB}$ image on inner self-expressive value of luxury brands will be greater with the increase in the strength of brandcountry association.

Based on the analysis above, we expect that due to social normalization COB image has a negative effect on uniqueness of symbolic value. That is, the better the country image is, the more normative the COB image is. It meets most people's values, but is detrimental to consumers seeking uniqueness. Given that COB image lacks links with brands, social normalization of $\mathrm{COB}$ image will have less impact on consumers' perceived uniqueness value. In other words, the negative effect of COB image on uniqueness value will decline. Formally, we propose

H11: The effect of COB image on uniqueness value of luxury brands will be greater with the increase in the strength of brand-country association.

Next, we present two studies that are designed to test our predictions, including COB image $\times$ regulatory focus interactions, and $\mathrm{COB}$ image $\times$ strength of brand-country association interactions.

\section{Study 1 Cob Image and Regulatory Focus}

The purpose of study 1 is to test $\mathrm{H} 1$ through H7, inclusive. For the empirical test of the hypotheses, we employed two experiments to examine the influence of $\mathrm{COB}$ image and symbolic value due to the differences in promotion focus and prevention focus. Sunglasses were used as stimuli in Experiment 1, while sunscreen creams were used in Experiment 2.

Subjects for the pilot study and for the main study were 30 and 169 undergraduate students, respectively, in China. Students are suited for purposes of this study because (1) prior research with respect to luxury goods and premium goods (e.g. cars, houses) used students as subjects with satisfactory results (Belk, Mayer, \&Bahn, 1982 ; Belk, Mayer, \& Bahn, 1984; Wilcox, Min, \& Sen, 2009; Wilfred \& Sanjay , 2005; Heribert \& Verena, 2010); (2) Chinese luxury consumers are generally younger, of which $80 \%$ are under age of 45 , compared with $30 \%$ in the United States and 19\% in Japan (McKinsey, 2011). A huge and young emerging consumer group is a significant feature for the Chinese luxury market (Ruder Finn, Albatross, 2011), which indicates that students are likely to be important actual or potential consumers of luxury goods; (3) given that there is high homogeneity in student samples, it is helpful to avoid interference of subjects in variables, with high internal validity (Shuptrine, 1975).

We first adjust the subjects' mood with music and pictures because Keller, Lipkus, and Rimer (2003) proposed that subjects' mood had an effect on experiment results to some extent. Thus, we played light music or showed pictures before the experiments 
in order to relax subjects. We then randomly issued questionnaires in non-numerical sequence after explaining the instructions. With the intent of controlling experiments strictly, we neither informed the subjects of the real purpose of this experiment, nor let them know that there were several different questionnaire types. Subjects who identified the research intentions of the experiment were excluded. Next, the subjects were asked to read the questionnaires and assess the extent of their perception as to luxury consumption. Finally, we collected the subjects' demographic characteristics. Each was given a gift valued at RMB 10 as a gesture of gratitude after the experiment.

\section{Experiment 1}

A two (COB image) by two (regulatory focus) between-subjects full-factorial design was used. Sunglasses are well-suited for the purpose of the study because that (1) Luxury Accessories (e.g. sunglasses) in 2013 were one of eight luxury products with more than one billion dollars of consumption for consumers in mainland China (BAIN \& COMPANY, 2013); (2) sunglasses are goods consumed in public; therefore, such consumption may imply more social meaning; (3) prior research used sunglasses as stimuli with satisfactory results (Piron, 2000; Khan \& Dhar, 2006).

A pilot study was conducted in order to identify two countries that differ significantly in their $\mathrm{COB}$ image with respect to sunglasses. We assess the $\mathrm{COB}$ image toward luxury brands on seven-point Likert scales (Roth \& Romeo, 1992; Martin \& Eroglu, 1993; Pereira, Hsu, \& Kundu, 2005; Laroche et al., 2005). Subjects rated the COB image of luxury goods originating from eight different countries. A total of 30 questionnaires were distributed, of which 36 were returned resulting in a satisfactory response rate of 90 percent. Based on the results of the pilot study, France and China were selected respectively as favorable image and unfavorable image due to the significant difference in COB image. Mock brands of ÉTÉ and Prosee were chosen as French and China brands rather than choosing known brands in order to control the image inferences from the brand name.

We assess regulatory focus with the six-item measure (Higgins et al., 1994), which incorporate strategiesassociated with being good friends. Three items imply a promotion focus, including (1) "Be generous and willing to give of yourself"; (2) "Be supportive to your friends. Be emotionally supportive"; (3) "Be loving and attentive." While the remaining three items are used more by prevention-focused subjects, such as: (4) "Stay in touch. Don't lose contact with friends"; (5) "Try to make time for your friends and don't neglect them"; (6) "Keep the secrets friends have told you and don't gossip about friends." Previous research seldom, if ever, used the measure to assess promotion and prevention goals (e.g. Sengupta \& Zhou, 2007). Based on the results of measurement, subjects were primed into promotion focus and prevention focus conditions. Thus, we have a $2 \times 2$ mixed design in the study.

A total of 89 undergraduates took part in Experiment 1. They were asked to read materials carefully and answer the questions. 69 questionnaires were usable $(84.1 \%$ female) excluding the invalid samples (e.g. missing values).

\section{Manipulation Checks}


We assessed COB image on a seven-point Likert scale, which included a four-item measure of COB image (e.g., " I feel that $\mathrm{X}$ is a developed country "; $\alpha=.910$ ), adapted from the work of Roth and Romeo(1992), Martin and Eroglu (1993), Pereira, Hsu, \& Kundu (2005), Laroche et al. (2005); a four-item measure of prestige value (e.g., "Luxury brands originating from COB of X are the symbol of status", $\alpha=$ .889), adapted from the work of Tsai (2005) and Rio, Vazquez, and Iglesias (2001); a four-item measure of social self-expressive value (e.g., "the brand reflects my background", $\alpha=.891$ ), adapted from the work of Tsai (2005) and Rio et al. (2001); a four-item measure of inner self-expressive value (e.g., "the brand reflects lifestyle", $\alpha$ $=.837$ ), adapted from the work of Tsai (2005); a four-item measure of uniqueness value (e.g., "the brand reflects my distinction", $\alpha=.715$ ), adapted from the work of Ruvio, Shoham, and Brencic (2008). All multi-item measures were reliable, above the suggested threshold of .70 (Fornell \& Larcker, 1981).

We ran ANOVA with the purpose of testing manipulation effects on COB image. The difference between mean ratings within the category of sunglasses is statistically significant, that is, France was higher on $\mathrm{COB}$ image measure compared to China ( $\left.\mathrm{M}_{\text {Favorable }}=5.96, \mathrm{M}_{\text {Unfavorable }}=3.84, \mathrm{~F}=62.951, \mathrm{p}<0.001\right)$. We concluded that the manipulation was successful.

\section{Results}

The model used in the analyses to test hypotheses from $\mathrm{H} 1$ to $\mathrm{H} 7$ is a MANOVA model, with COB image (favorable vs. unfavorable) and regulatory focus (promotion focus vs. prevention focus) as between-subject factors. The dependent variables were prestige value, social self-expressive value, inner self-expressive value, and uniqueness value. $\mathrm{H} 1, \mathrm{H} 2, \mathrm{H} 3$ and $\mathrm{H} 4$ predict, respectively, whether $\mathrm{COB}$ image has a positive effect on prestige value, social self-expressive value, and inner selfexpressive value; conversely, whether $\mathrm{COB}$ image has a negative effect on uniqueness value.

As suggested by $\mathrm{H} 1$, the positive effect of $\mathrm{COB}$ image on prestige value is significant $\left(\mathrm{M}_{\text {Favorable }}=4.385, \mathrm{M}_{\text {Unfavorable }}=3.500, \mathrm{~F}=5.595, \mathrm{p}<0.05\right)$. We find that consumers will perceive more prestige value when COB image is favorable. In line with $\mathrm{H} 2$ and $\mathrm{H} 3$, $\mathrm{COB}$ image was a significant, positive predictor of social self-expressive value $(\mathrm{F}=75.203, \mathrm{p}<0.001)$, and inner self-expressive value $(\mathrm{F}=25.146, \mathrm{p}<0.001)$. Whereas a favorable COB image has a negative effect on uniqueness value (Mavorable $=3.484, \mathrm{M}_{\text {Unfavorable }}=4.527, \mathrm{~F}=23.464, \mathrm{p}<0.001$ ). In other words, consumers will perceive more uniqueness value when $\mathrm{COB}$ image is unfavorable.

Given our prediction regarding the moderating effect of regulatory focus on the interaction between COB image and prestige value (i.e., H5), however, it is found that COB image $\times$ prestige value was not significant $(p>0.1)$. H6 predicted that favorable $\mathrm{COB}$ image would have a stronger effect on social self-expressive value of luxury brands for subjects with promotion focus than those with prevention focus. Consistent with this hypothesis (see Table 1 and Figure 1), we obtained that promotion-focused subjects would perceive more social self-expressive value due to favorable $\mathrm{COB}$ image than prevention-focused subjects $(\mathrm{F}=7.962, \mathrm{p}<0.01)$. Similarly, as $\mathrm{H} 7$ predicted, the more favorable $\mathrm{COB}$ image would induce more inner self-expressive value for the subjects with promotion focus $(\mathrm{F}=6.450, \mathrm{p}<0.05)$. 
In summary, this study provides evidence for the central convention that COB image has a positive effect on prestige value, social self-expressive value, inner selfexpressive value, and a negative effect on uniqueness value. Subjects with promotion focus will perceive more social self-expressive and inner self-expressive value.

Table 1: Experiment1: Results of statistics tests

\begin{tabular}{l|c|c|c|c}
\hline $\begin{array}{c}\text { Dependent } \\
\text { variables }\end{array}$ & Prestige value & $\begin{array}{c}\text { Social self- } \\
\text { expressive value }\end{array}$ & $\begin{array}{c}\text { Inner self- } \\
\text { expressive value }\end{array}$ & $\begin{array}{c}\text { Uniqueness } \\
\text { value }\end{array}$ \\
\hline Interpolation & $\begin{array}{c}444.512 * \\
(0.000)\end{array}$ & $\begin{array}{c}821.656 \\
(0.000)\end{array}$ & $\begin{array}{c}614.837 \\
(0.000)\end{array}$ & $\begin{array}{c}1385.147 \\
(0.000)\end{array}$ \\
\hline COB image & 5.595 & 75.203 & 25.146 & 23.464 \\
$(0.021)$ & $(0.000)$ & $(0.000)$ & $(0.000)$ \\
\hline Regulatory & 0.001 & 16.584 & 12.495 & 0.118 \\
focus & $(0.974)$ & $(0.000)$ & $(0.001)$ & $(0.732)$ \\
\hline COB image $\times$ & 0.252 & 7.962 & 6.450 & 3.364 \\
regulatory & $(0.617)$ & $(0.006)$ & $(0.013)$ & $(0.071)$ \\
focus & & &
\end{tabular}

Notes: P-value is given between brackets

Social self-expressive value|

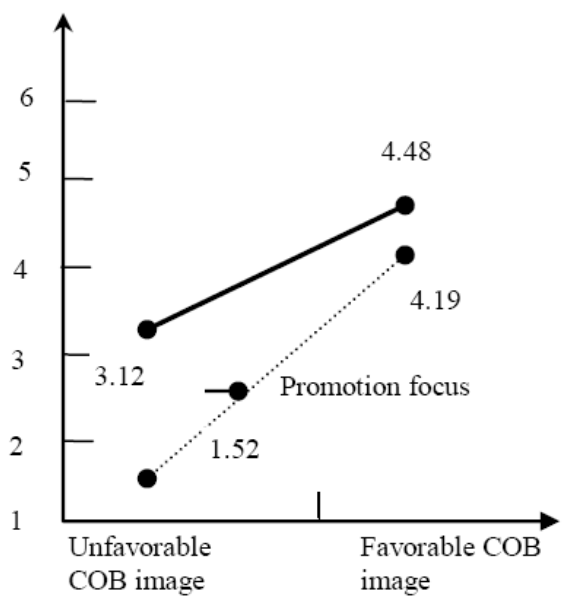

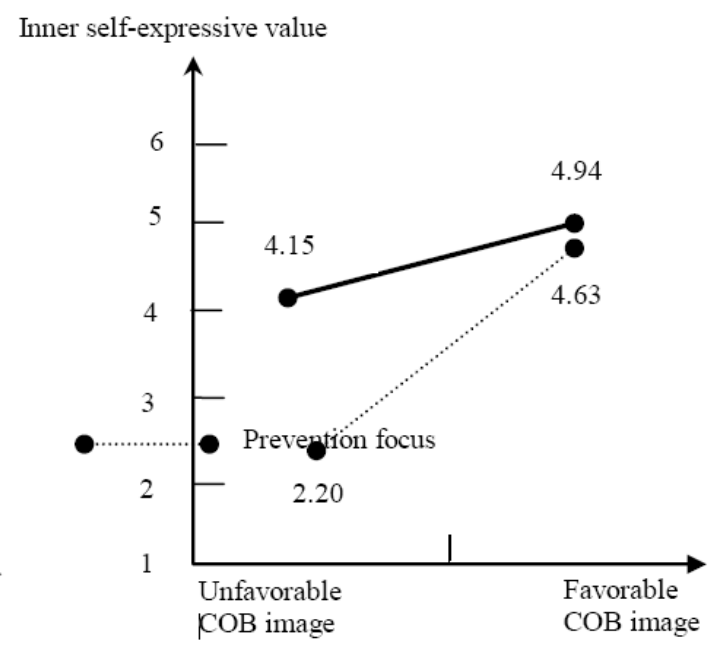

Figure 1: Social self-expressive value and Inner self-expressive value across $\mathrm{COB}$ image by regulatory focus in Experiment 1

\section{Experiment 2}

Although Experiment 1 provides evidence for most hypotheses, it needs improvement because: (1) in spite of real COB we selected from the pilot, it is difficult to avoid preconceived understanding of $\mathrm{COB}$, which may have interfered with validation of conclusions; (2) Bourne (1956) suggested that luxury goods consisted of publicly consumed products and privately consumed products. In Experiment 1, we used publicly consumed sunglasses as the stimuli. We wonder if the results will be the same, when we use privately consumed luxury goods instead; (3) Regulatory focus is not only a chronic self-regulation goal, in some cases, subjects can be 'framed' temporarily into either a promotion focus or a prevention focus context (Lockwood, Jordan, \& Kunda, 2002). We measured the subjects' chronic regulatory focus in Experiment 1, but situational regulatory focuses were not involved. 
Hence, we adjusted the design of Experiment 2 as follows: (1) In Experiment 2, we created mock countries instead of France and China, using Countries A and B as standing for $\mathrm{COB}$ with favorable and unfavorable image respectively; (2) we selected a privately consumed sunscreen cream as stimuli instead of publicly consumed sunglasses. A pretest was conducted to identify the right luxury categories in experiments. The pretest showed that cosmetics were one of the main luxuries; $60 \%$ of interviewees purchased premium cosmetics. Premium cosmetics consumption for consumers of mainland China was in the first place (BAIN \& COMPANY, 2013). Although luxury watches were in the downturn in 2013, premium cosmetics consumption was expected to be increasing in 2014 (Ruder Finn, 2014). In view of the experiment design for regulatory focus, we select premium sunscreen cream as stimuli. Sunscreen cream are suited for the purpose of the study because prior research ever used sunscreen cream as stimuli with a satisfactory result (Lee \& Aaker, 2004); (3) we employed situational manipulation of regulatory focus rather than chronic measurement.

According to Blair and Innis (1996) and Teas and Agarwal (2000), we demonstrated stimuli with illustrations and captions so that subjects were framed into the context of luxury consumption of sunscreen cream. We mixed mock brands with two real luxury brands of skin care, expecting that subjects will take mock brands as real brands (e.g. sunny summer is coming. I would like to buy a sunscreen cream. It is said that Caillié(a mock brand), LACOME, Estee Lauder are all well-known brands for sunscreen creams).

Regulatory focus was manipulated using promotion-focused and prevention-focused magazine advertisings, adapted from the work of Lee and Aaker (2004), and Aaker and Lee (2001). In the promotion focus condition, the advertising of Caillié with the theme of "controlling Sunshine" is intended to activate subjects" focus on achieving positive outcomes of consumption, in which subjects will have a sense of control when consuming the sunscreen cream; conversely, in the prevention focus condition, the advertising of Caillie with the theme of "avoiding injury from sunshine" is used to evoke subjects' focus on avoiding the negative outcomes, in which subjects will feel a sense of security and the skin will be well protected.

A total of 80 undergraduates took part in Experiment 2. They were asked to read materials carefully and answer the questions. 66 questionnaires were left $(81.8 \%$ female) excluding the invalid samples (e.g. missing values).

\section{Manipulation Checks}

We assessed COB image on seven-point Likert scale, which included the same measure of COB image in Experiment $1(\alpha=.934)$; a four-item measure of prestige value $(\alpha=.722)$, according to the measures of Tsai (2005) and Rio, Vazquez, and Iglesias (2001); a four-item measure of social self-expressive value $(\alpha=.854)$, according to the measures of Tsai (2005) and Rio et al. (2001); a four-item measure of inner self-expressive value $(\alpha=.782)$, according to the measures of Tsai (2005); a four-item measure of uniqueness value $(\alpha=.810)$, adapted from the work of Ruvio et al.(2008). All multi-item measures were reliable, above the suggested threshold of .70 . 
We ran ANOVA with the purpose of testing manipulation effects on COB image and regulatory focus. The difference between mean ratings within the category of sunglasses is statistically significant, that is, Country A was higher on COB image measure compared to Country B $\left(\mathrm{M}_{\text {Favorable }}=5.80, \mathrm{M}_{\text {Unfavorable }}=2.63, \mathrm{~F}=167.561\right.$, $\mathrm{p}<0.001)$; the difference between mean ratings with regard to promotion focus and prevention focus is also statistically significant (Mromotion $=4.42, M_{\text {Prevention }}=2.90$, $\mathrm{F}=46.042, \mathrm{p}<0.001)$. We concluded that both of the manipulations were successful.

\section{Results}

The model used to test hypotheses from $\mathrm{H} 1$ to $\mathrm{H} 7$ is a MANOVA model, with $\mathrm{COB}$ image (favorable vs. unfavorable) and regulatory focus (promotion focus vs. prevention focus) as between-subject factors. The dependent variables were prestige value, social self-expressive value, inner self-expressive value, and uniqueness value. $\mathrm{H} 1, \mathrm{H} 2, \mathrm{H} 3$ and $\mathrm{H} 4$ predict respectively that whether $\mathrm{COB}$ image has a positive effect on prestige value, social self-expressive value, and inner self-expressive value; conversely, whether COB image has a negative effect on uniqueness value.

As suggested by $\mathrm{H} 1$, the positive effect of $\mathrm{COB}$ image on prestige value was significant $\left(\mathrm{M}_{\text {Favorable }}=4.423\right.$, $\left.\mathrm{M}_{\text {Unfavorable }}=3.397, \mathrm{~F}=51.194, \mathrm{p}<0.001\right)$. We find that consumers will perceive more prestige value when $\mathrm{COB}$ image is favorable. In line with $\mathrm{H} 2$ and $\mathrm{H} 3, \mathrm{COB}$ image was a significant, positive predictor of social selfexpressive value $(\mathrm{F}=16.468, \mathrm{p}<0.001$, and inner self-expressive value $(\mathrm{F}=74.413$, $\mathrm{p}<0.001)$.

Whereas a favorable $\mathrm{COB}$ image has a negative effect on uniqueness value $\left(\mathrm{M}_{\text {Favorable }}=3.183, \mathrm{M}_{\text {Unfavorable }}=3.982, \mathrm{~F}=7.408, \mathrm{p}<0.01\right)$. In other words, consumers will perceive more uniqueness value when $\mathrm{COB}$ image is unfavorable.

Given our prediction regarding the moderating effect of regulatory focus on the relationship between $\mathrm{COB}$ image and prestige value (i.e., H5), however, it is found that $\mathrm{COB}$ image $\times$ prestige value was not significant $(p>0.05)$. H6 predicted that favorable COB image would have a stronger effect on social self-expressive value of luxury brands when subjects are promotion focused,rather than prevention focused. Consistent with this hypothesis (see Table 2 and Figure 2), we obtained that promotion-focused subjects will perceive more social self-expressive value due to favorable COB image than prevention-focused subjects $(\mathrm{F}=7.077, \mathrm{p}<0.05)$. Similarly, as $\mathrm{H} 7$ predicted, the more favorable COB image will induce more inner self-expressive value for the subjects with a promotion focus $(F=6.590, p<0.05)$.

In summary, this study provides evidence for the central contention that $\mathrm{COB}$ image has a positive effect on prestige value, social self-expressive value, inner selfexpressive value, and a negative effect on uniqueness value. Subjects with promotion focus will perceive more social self-expressive and inner self-expressive value.

\section{Study 2 Cob Image and Strength Of Brand-Country Association}

The purpose of study 2 is to test $\mathrm{H} 1, \mathrm{H} 2, \mathrm{H} 3, \mathrm{H} 4, \mathrm{H} 8, \mathrm{H} 9, \mathrm{H} 10$, and $\mathrm{H} 11$. For the empirical test of the hypotheses, we employed two experiments to examine the influence of COB image and symbolic value due to the differences in the strength of brand-country association. Sunglasses were used as stimuli in Experiment 1, while 
sunscreen creams were also used in Experiment 2. Subjects for the main study were 217 undergraduate students in China, which are different from the subjects in Study 1. The experiment process in this study is the same with that in Study 1.

Table 2: Experiment 2: Results of statistics tests

\begin{tabular}{l|c|c|c|c}
\hline \multicolumn{1}{c|}{$\begin{array}{c}\text { Dependent } \\
\text { variables }\end{array}$} & $\begin{array}{c}\text { Prestige } \\
\text { value }\end{array}$ & $\begin{array}{c}\text { Social self- } \\
\text { expressive value }\end{array}$ & $\begin{array}{c}\text { Inner self- } \\
\text { expressive value }\end{array}$ & $\begin{array}{c}\text { Uniqueness } \\
\text { value }\end{array}$ \\
\hline Interpolation & $\begin{array}{c}2969.314^{*} \\
(0.000)\end{array}$ & $\begin{array}{c}694.665 \\
(0.000)\end{array}$ & $\begin{array}{c}1869.706 \\
(0.000)\end{array}$ & $\begin{array}{c}595.898 \\
(0.000)\end{array}$ \\
\hline COB image & $\begin{array}{c}51.194 \\
(0.000)\end{array}$ & $\begin{array}{c}16.468 \\
(0.000)\end{array}$ & $\begin{array}{c}74.413 \\
(0.000)\end{array}$ & $\begin{array}{c}7.408 \\
(0.008)\end{array}$ \\
\hline $\begin{array}{l}\text { Regulatory } \\
\text { focus }\end{array}$ & $\begin{array}{c}15.653 \\
(0.000)\end{array}$ & $\begin{array}{c}9.829 \\
(0.003)\end{array}$ & $\begin{array}{c}58.396 \\
(0.000)\end{array}$ & $\begin{array}{c}10.480 \\
(0.002)\end{array}$ \\
\hline $\begin{array}{l}\text { COB image } \times \\
\text { regulatory } \\
\text { focus }\end{array}$ & 2.875 & 7.077 & 6.590 & 0.652 \\
\hline
\end{tabular}

Notes: P-value is given between brackets.
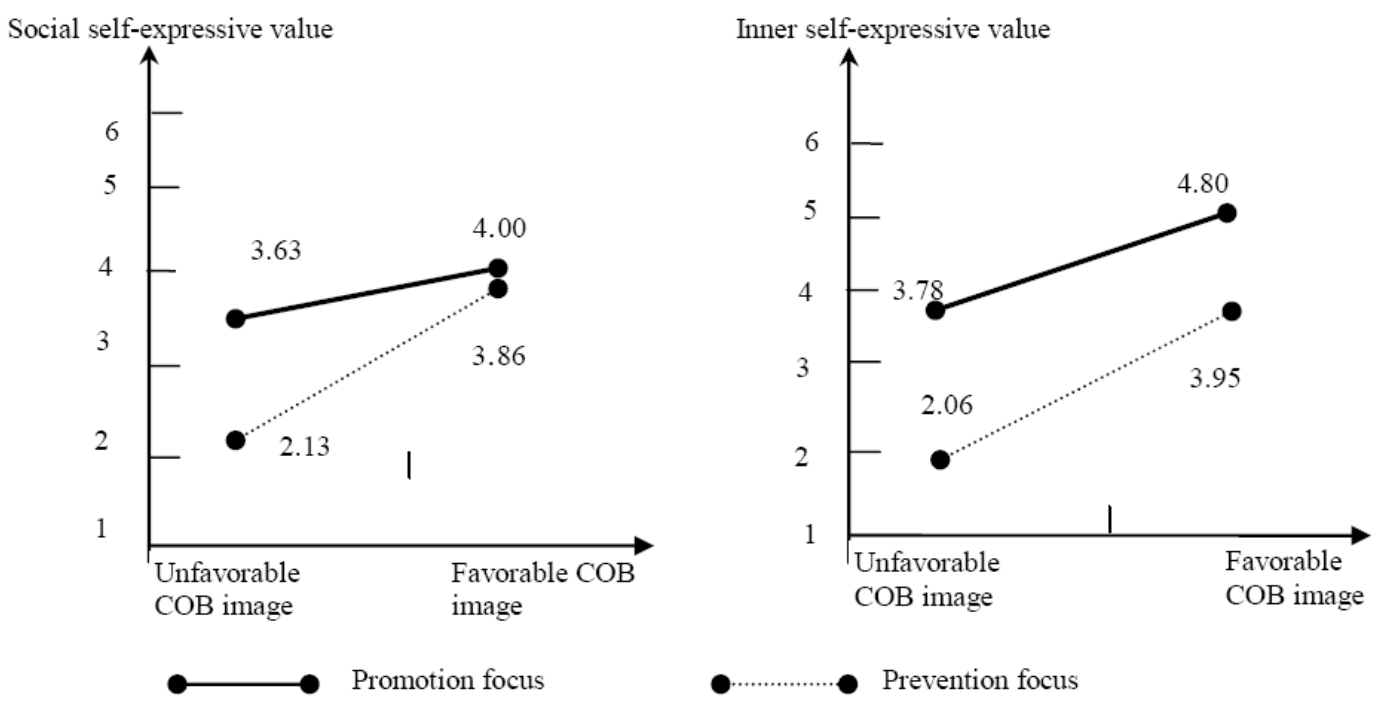

Figure 2: Social self-expressive value and Inner self-expressive value across COB image by regulatory focus in Experiment 2

\section{Experiment 1}

A two (COB image) by two (Strength of brand-country association) between-subjects full-factorial design was used. Based on the results of the pilot study, France(French) and China were selected respectively as favorable image and unfavorable image due to the significant difference in COB image. Strength of brand-country association was framed into two conditions (high vs. low). In high strength of brand-country association context, we focus on "French" or "China" repeatedly in order to highlight the association between the brand and COB. For example, in French context, we elaborated the brand of ÉTÉ like "It was originated from Beauvais in Normandy, andcreated by French designer ALAIN ÉTÉ. For over 100 years, there has been nothing more French than ÉTÉ...According to the survey of luxury brands by Ogilvy \& Mather, ÉTÉ has been the French brand which global consumers most admire". While, in low strength of brand-country association context, we never 
mentioned any COB related words. Mock brands of ÉTÉ and Prosee were chosen as French and China brands rather than choosing known brands. 84 undergraduates took part in Experiment 1. They were asked to read materials carefully and answer the questions. 68 questionnaires were left $(58.8 \%$ female) excluding the invalid samples (e.g. missing values).

\section{Manipulation Checks}

We assessed COB image on a seven-point Likert scale, which included the same measure of COB image as in Study $1(\alpha=.888)$, according to the measures of Roth and Romeo (1992), Martin and Eroglu (1993), Pereira, Hsu, \& Kundu (2005), Laroche et al. (2005); a three-item measure of strength of brand-country association $(\alpha$ $=.780$ ), according to the measures adapted from the work of Haubl and Elrod (1999); a four-item measure of prestige value $(\alpha=.912)$, according to the measures of Tsai (2005) and Rio, Vazquez, and Iglesias (2001); a four-item measure of social selfexpressive value ( $\alpha=.841)$, according to the measures of Tsai (2005) and Rio et al.(2001); a four-item measure of inner self-expressive value $(\alpha=.800)$, according to the measures of Tsai (2005); a four-item measure of uniqueness value $(\alpha=.829)$, adapted from the work of Ruvio et al.(2008). All multi-item measures were reliable, above the suggested threshold of .70 .

We ran ANOVA with the purpose of testing manipulation effects on COB image and strength of brand-country association. The difference between mean ratings within the category of sunglasses is statistically significant, that is, French was higher on COB image measure compared to China $\left(\mathrm{M}_{\text {Favorable }}=5.28, \mathrm{M}_{\text {Unfavorable }}=3.47, \mathrm{~F}=36.422\right.$, $\mathrm{p}<0.001$ ); the difference between mean ratings with regard to strength of brandcountry association is also statistically significant $\left(\mathrm{M}_{\text {Promotion }}=4.74, \mathrm{M}_{\text {Prevention }}=3.25\right.$, $\mathrm{F}=31.629, \mathrm{p}<0.001)$. We concluded that both of the manipulations were successful.

\section{Results}

The model used to test hypotheses from $\mathrm{H} 1$ to $\mathrm{H} 4$ and from $\mathrm{H} 8$ to $\mathrm{H} 11$ is a MANOVA model, with COB image (favorable vs. unfavorable) and strength of brand-country association (high vs. low) as between-subjects factors. The dependent variables were prestige value, social self-expressive value, inner self-expressive value, and uniqueness value. $\mathrm{H} 1, \mathrm{H} 2, \mathrm{H} 3$ and $\mathrm{H} 4$ predict, respectively, whether $\mathrm{COB}$ image has a positive effect on prestige value, social self-expressive value, and inner selfexpressive value; or, conversely, whether $\mathrm{COB}$ image has a negative effect on uniqueness value.

As suggested by $\mathrm{H} 1$, the positive effect of $\mathrm{COB}$ image on prestige value was significant $\left(\mathrm{M}_{\text {Favorable }}=4.59, \mathrm{M}_{\text {Unfavorable }}=2.35, \mathrm{~F}=144.484, \mathrm{p}<0.001\right)$. We find that consumers will perceive more prestige value when $\mathrm{COB}$ image is favorable. In line with $\mathrm{H} 2$ and $\mathrm{H} 3, \mathrm{COB}$ image was a significant and positive predictor of social selfexpressive value $(\mathrm{F}=21.794, \mathrm{p}<0.001)$ and inner self-expressive value $(\mathrm{F}=10.452$, $\mathrm{p}<0.01)$. Whereas a favorable $\mathrm{COB}$ image has a negative effect on uniqueness value $(\mathrm{F}=40.760, \mathrm{p}<0.001)$.

As suggested by $\mathrm{H} 8$, the moderating effect of strength of brand-country association on the relationship between $\mathrm{COB}$ image $\times$ prestige value was significant $(\mathrm{F}=7.403$, 
$\mathrm{p}<0.01)$. H9 predicted that favorable COB image would have a stronger effect on social self-expressive value of luxury brands when there is higher strength of brandcountry association. Consistent with this hypothesis (see Table 3 and Figure 3), we obtained that subjects will perceive more social self-expressive value due to favorable $\mathrm{COB}$ image when brands are closely associated with $\mathrm{COB}(\mathrm{F}=7.316, \mathrm{p}<0.01)$. As $\mathrm{H} 10$ and $\mathrm{H} 11$ predicted, more favorable $\mathrm{COB}$ image will induce more inner selfexpressive value $(\mathrm{F}=4.653, \mathrm{p}<0.05)$ and less uniqueness value in the higher strength of brand-country association condition $(\mathrm{F}=7.273, \mathrm{p}<0.01)$.

In summary, this study provides evidence for the central convention that COB image has a positive effect on prestige value, social self-expressive value, inner selfexpressive value, and a negative effect on uniqueness value. Strength of brandcountry association would moderate the interaction between $\mathrm{COB}$ image and symbolic value.

Table 3: Experiment 1: Results of statistics tests

\begin{tabular}{l|c|c|c|c}
\hline $\begin{array}{l}\text { Dependent } \\
\text { variables }\end{array}$ & Prestige value & $\begin{array}{c}\text { Social self- } \\
\text { expressive value }\end{array}$ & $\begin{array}{c}\text { Inner self- } \\
\text { expressive value }\end{array}$ & $\begin{array}{c}\text { Uniqueness } \\
\text { value }\end{array}$ \\
\hline Interpolation & $\begin{array}{c}1390.580^{*} \\
(0.000)\end{array}$ & $\begin{array}{c}612.073 \\
(0.000)\end{array}$ & $\begin{array}{c}625.753 \\
(0.000)\end{array}$ & $\begin{array}{c}909.658 \\
(0.000)\end{array}$ \\
\hline COB image & $\begin{array}{c}144.484 \\
(0.000)\end{array}$ & $\begin{array}{c}21.794 \\
(0.000)\end{array}$ & $\begin{array}{c}10.452 \\
(0.002)\end{array}$ & $\begin{array}{c}40.760 \\
(0.000)\end{array}$ \\
\hline $\begin{array}{l}\text { strength of } \\
\text { brand-country } \\
\text { association }\end{array}$ & $\begin{array}{c}29.208 \\
(0.000)\end{array}$ & $\begin{array}{c}4.902 \\
(0.030)\end{array}$ & $\begin{array}{c}8.156 \\
(0.006)\end{array}$ & $\begin{array}{c}5.092 \\
(0.027)\end{array}$ \\
\hline $\begin{array}{l}\text { COB image } \\
\text { strength of } \\
\text { brand-country } \\
\text { association }\end{array}$ & $\begin{array}{c}7.403 \\
\text { (0.008) }\end{array}$ & $\begin{array}{c}7.316 \\
(0.009)\end{array}$ & $\begin{array}{c}4.653 \\
(0.035)\end{array}$ & $\begin{array}{c}7.273 \\
(0.009)\end{array}$ \\
\hline
\end{tabular}

Notes: P-value is given between brackets.
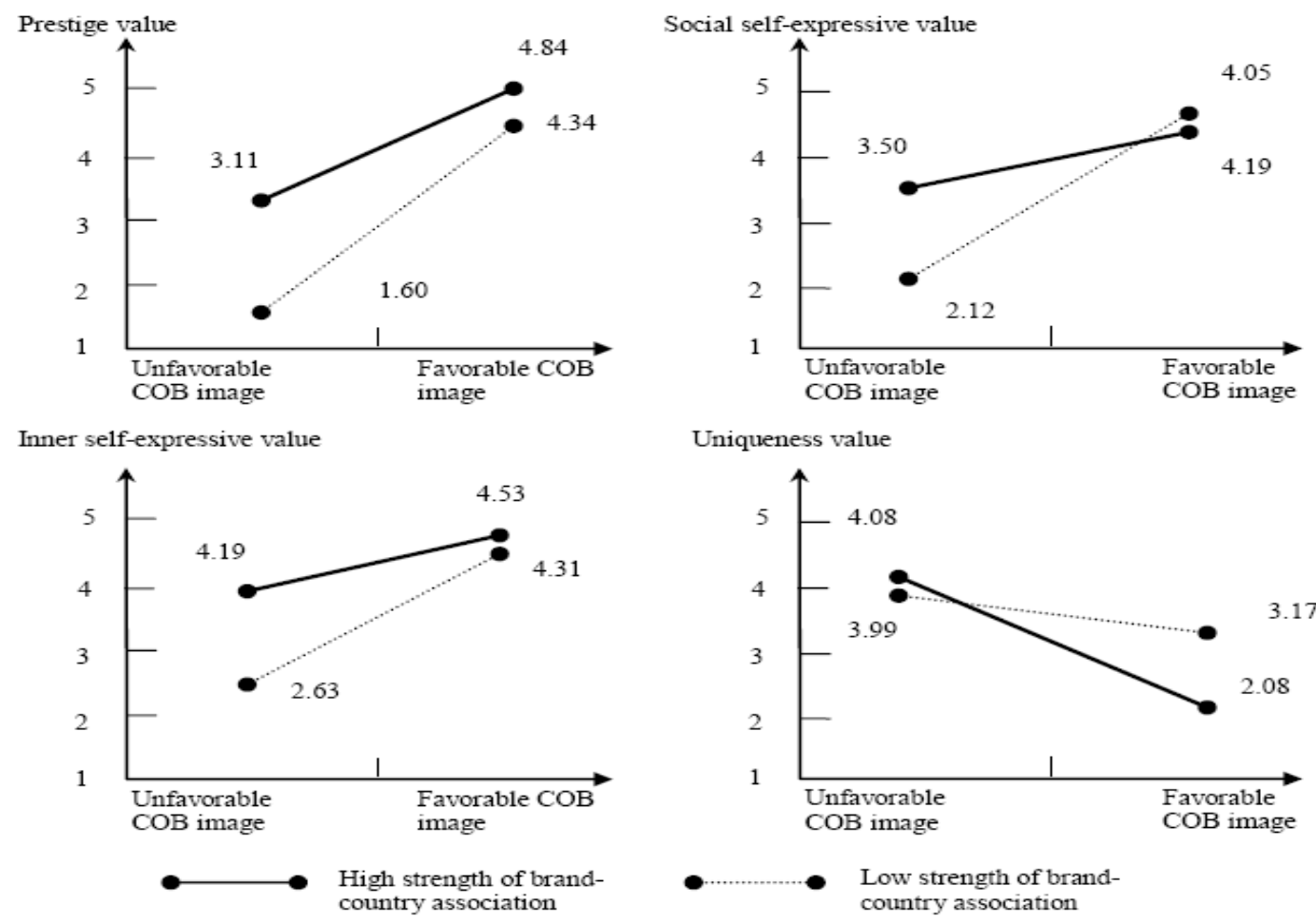
Figure 3: Symbolic value across COB image by strength of brand-country association in Experiment 1

\section{Experiment 2}

A two (COB image) by two (Strength of brand-country association) between-subjects full-factorial design was used. In Experiment 2 we created mock countries instead of France and China, of which Countries A and B stand for COB with favorable and unfavorable image respectively. Strength of brand-country association was framed into two conditions (high vs. low). Mock brand "Caillié" of sunscreen cream was created for Experiment 2. We manipulated COB image and strength of brand-country association with scenario simulation. 133 undergraduates took part in Experiment 2. They were asked to read materials carefully and answer the questions. 117 questionnaires were left ( $74.4 \%$ female) excluding the invalid samples (e.g. missing values).

\section{Manipulation Checks}

We assessed COB image on a seven-point Likert scale, which included the same measure of COB image in Study $1(\alpha=.948)$, adapted from the measures of Roth and Romeo (1992), Martin and Eroglu (1993), Pereira, Hsu, \& Kundu (2005), Laroche et al. (2005); a three-item measure of strength of brand-country association $(\alpha=.896)$, adapted from the work of Haubl and Elrod (1999); a four-item measure of prestige value $(\alpha=.882)$, according to the measures of Tsai (2005) and Rio, Vazquez, and Iglesias (2001); a four-item measure of social self-expressive value $(\alpha=.868)$, according to the measures of Tsai (2005) and Rio et al. (2001); a four-item measure of inner self-expressive value $(\alpha=.783)$, using the measures of Tsai (2005); a four-item measure of uniqueness value $(\alpha=.794)$, adapted from the work of Ruvio et al.(2008). All multi-item measures were reliable, above the suggested threshold of .70.

We ran ANOVA with the purpose of testing manipulation effects on COB image and strength of brand-country association. The difference between mean ratings within the category of sunscreen cream is statistically significant, that is, Country A was higher on COB image measure compared with Country B ( $\mathrm{M}_{\text {Favorable }}=5.58, \mathrm{M}_{\text {Unfavorable }}=2.05$, $\mathrm{F}=448.808, \mathrm{p}<0.001$ ); the difference between mean ratings with regard to strength of brand-country association is also statistically significant (Mromotion=5.08, $\left.\mathrm{M}_{\text {Prevention }}=2.92, \mathrm{~F}=60.459, \mathrm{p}<0.001\right)$. We concluded that both of the manipulations were successful.

\section{Results}

The model used to test hypotheses from $\mathrm{H} 1$ to $\mathrm{H} 4$ and from $\mathrm{H} 8$ to $\mathrm{H} 11$ is a MANOVA model, with COB image (favorable vs. unfavorable) and strength of brand-country association (high vs. low) as between-subject factors. As suggested by $\mathrm{H} 1$, the positive effect of $\mathrm{COB}$ image on prestige value was significant (Mavorable $=4.59, \mathrm{M}_{\text {Unfavorable }}=2.35, \mathrm{~F}=144.628, \mathrm{p}<0.001$ ). We find that consumers will perceive more prestige value when $\mathrm{COB}$ image is favorable. In line with $\mathrm{H} 2$ and $\mathrm{H} 3, \mathrm{COB}$ image was a significant, positive predictor of social self-expressive value $(\mathrm{F}=126.820$, $\mathrm{p}<0.001)$ and inner self-expressive value $(\mathrm{F}=59.726, \mathrm{p}<0.001)$. Whereas a favorable 
$\mathrm{COB}$ image has a negative effect on uniqueness value $(\mathrm{F}=21.268, \mathrm{p}<0.001)$. In other words, consumers will perceive less uniqueness value when $\mathrm{COB}$ image is favorable. As suggested by $\mathrm{H} 8$, the moderating effect of strength of brand-country association on the relationship between $\mathrm{COB}$ image $\times$ prestige value was significant $(\mathrm{F}=5.692$, $\mathrm{p}<0.05)$. H9 predicted that favorable COB image would have a stronger effect on social self-expressive value of luxury brands when there is higher strength of brandcountry association. Consistent with this hypothesis (see Table 4 and Figure 4), we obtained that subjects will perceive more social self-expressive value due to favorable COB image when brands are significantly associated with $\mathrm{COB}(\mathrm{F}=7.198, \mathrm{p}<0.01)$. Similarly, as $\mathrm{H} 10$ and $\mathrm{H} 11$ predicted, the more favorable $\mathrm{COB}$ image will induce more inner self-expressive value $(\mathrm{F}=6.077, \mathrm{p}<0.05)$ and less uniqueness value in the higher strength of brand-country association condition $(F=5.836, p<0.05)$.

Table 4: Experiment 2: Results of statistics tests

\begin{tabular}{l|c|c|c|c}
\hline $\begin{array}{l}\text { Dependent } \\
\text { variables }\end{array}$ & Prestige value & $\begin{array}{c}\text { Social self- } \\
\text { expressive value }\end{array}$ & $\begin{array}{c}\text { Inner self- } \\
\text { expressive value }\end{array}$ & $\begin{array}{c}\text { Uniqueness } \\
\text { value }\end{array}$ \\
\hline Interpolation & $\begin{array}{c}2191.877^{*} \\
(0.000)\end{array}$ & $\begin{array}{c}2408.488 \\
(0.000)\end{array}$ & $\begin{array}{c}1718.776 \\
(0.000)\end{array}$ & $\begin{array}{c}1268.603 \\
(0.000)\end{array}$ \\
\hline COB image & $\begin{array}{c}144.628 \\
(0.000)\end{array}$ & $\begin{array}{l}126.820 \\
(0.000)\end{array}$ & $\begin{array}{c}59.726 \\
(0.000)\end{array}$ & $\begin{array}{c}21.268 \\
(0.000)\end{array}$ \\
\hline $\begin{array}{l}\text { strength of } \\
\text { brand-country } \\
\text { association }\end{array}$ & $\begin{array}{l}137.618 \\
(0.000)\end{array}$ & $\begin{array}{l}135.554 \\
(0.000)\end{array}$ & $\begin{array}{c}37.458 \\
(0.000)\end{array}$ & $\begin{array}{l}24.562 \\
(0.000)\end{array}$ \\
\hline $\begin{array}{l}\text { COB image } \\
\text { strength of } \\
\text { brand-country } \\
\text { association }\end{array}$ & 5.692 & 7.198 & 6.077 & 5.836 \\
\hline
\end{tabular}

Notes: P-value is given between brackets.
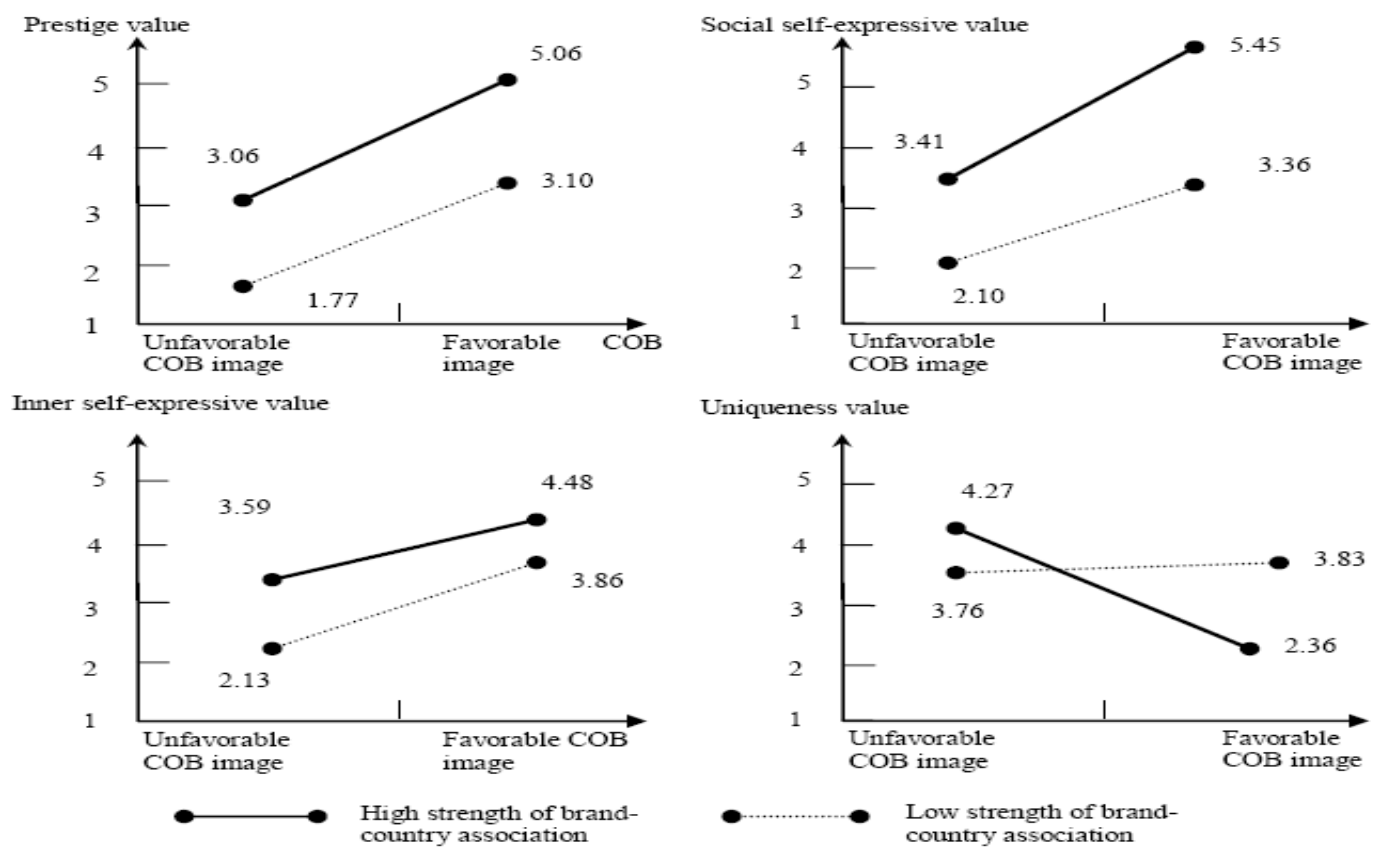

Figure 4: Symbolic value across COB image by strength of brand-country association in Experiment 2 
In summary, this study provides evidence for the central contention that COB image has a positive effect on prestige value, social self-expressive value, inner selfexpressive value, and a negative effect on uniqueness value. Strength of brandcountry association would moderate the interaction between COB image and symbolic value.

\section{General Discussion}

\section{Conclusion}

This paper employed two studies in order to explore the effect of COB image on symbolic value of luxury brands, and the moderation effects of regulatory focus and strength of brand-country association. Across two studies, the findings of the empirical study of symbolic value relative to the COB image of luxury sunglasses and sunscreen cream provide strong support for our hypotheses. Specifically, the research suggests that a favorable COB image will increase prestige value, social selfexpressive value, inner self-expressive value, but will decrease uniqueness value. Importantly, we provide convergent evidence that regulatory focus and strength of brand-country association moderate the relationship between $\mathrm{COB}$ image and symbolic value. On the one hand, the research shows that consumers with promotion focus will be more emotionally vulnerable to influence by COB image, resulting in higher social self-expressive value and inner self-expressive value. On the other hand, when a brand is weakly associatedwith the image of the country, the effect of COB image on prestige value, social self-expressive value, inner self-expressive value, and uniqueness value will be weakened.

\section{Theoretical and Marketing Implications}

Numerous studies have documented that consumers use $\mathrm{COO}$ as extrinsic cues in identifying quality of goods (Chao, 1993; Erickson, Johansson, \& Chao, 1984; Han \& Terpstra, 1988). However, Hong and Wyer (1989) advanced that COB image also contained symbolic and emotional meanings in addition to functional value. Quester and Smart (1998) and Batra et al. (2000) also suggested that COB not only served as a perceived quality cue, but also contributed to status-enhancing, but the effect of COB on status is not examined empirically. Although Phau and Leng (2008) discovered that status-seeking teenagers preferred foreign luxury brands, they did not explain the relationship between $\mathrm{COB}$ image and symbolic value (e.g. status, self). This study extends the study of Quester and Smart (1998), Batra et al. (2000), Phau and Leng (2008) by empirically analyzing the relationship between COB image and symbolic value, which consists of prestige value, social self-expressive value, inner selfexpressive value, and uniqueness value. We expect that this study will be a beneficial supplement to prior COO effect studies.

This study also contributes to our understanding of luxury consumption by providing empirical evidence for $\mathrm{COB}$ effect on the symbolic value. Previous research indicated that $\mathrm{COO}$ effect worked in luxury consumption, i.e., COO image had more significant effect on purchase intention of luxury goods than that of necessities (Piron, 2000; Aiello et al., 2009; Godey et al., 2012). The prior research compared COO effect with price, design, and advertising, but neglected the effect of psychological and behavioral factors on COO effect of luxury goods. Since COB image, among other 
COO components, most effectively stimulates perceived value of luxury brands, examining the moderating role of regulatory focus in the relationship between COB image and symbolic consumption, enriches the luxury consumption literature. The research provides evidence that $\mathrm{COB}$ image functions in luxury symbolic consumption significantly for consumers with promotion focus, especially for perception of social self-expressive value and inner self-expressive value.

This research suggests that $\mathrm{COB}$ image has distinct effects on the components of symbolic value, which have implications for decisions related to communication campaigns. Specifically, undue emphasis on the superiority of COB image in publicity may not be able to actively stimulate consumer purchase desire. The current research finds that $\mathrm{COB}$ image had a negative impact on uniqueness value. Therefore, we suggest that luxury marketers should analyze the motivation of target customers before COB image communication.

This research also suggests that marketers consider how to control the situational factors through promotional activities to influence the symbolic value. In Study 1, the study demonstrates that two types of regulatory focus (promotion focus vs. prevention focus) constrained the COB effect in luxury consumption. Specifically, promotion focus will reinforce the $\mathrm{COB}$ effect on symbolic value. Thus, luxury marketers should develop communication programs, such as advertising with promotion-focus appeals, to prime targeted customers in favorable situations, especially for social selfexpressive value and inner self-expressive value seeking consumers. In such cases, COB effect will function more perfectly than prevention-focused situation. The moderation effect of regulatory focus offers implications for developing and implementing positioning strategy and communication campaign for international luxury marketers and local potential high-end brands marketers.

\section{Limitation and Future Studies}

We conclude by noting several limitations of the present work and by identifying what we view as promising opportunities for further research. First, this study emphasizesthe $\mathrm{COB}$ effect on luxury symbolic consumption from the psychological perspective (i.e. regulatory focus), while it neglects the effect of cross-cultural factors. Since international luxury marketers would face fierce challenges and opportunities from the cultural environment, cultural factors may vary according to the extent to which COB has an effect on symbolic value of luxury brands. The present framework could be expanded to include varying degrees of cultural factors (e.g. gift giving). A further limitation is that the method of these experiments lacks generality compared with survey and field studies. In future studies, it will prove promising to use field experiments or market surveys to test COB effect in the context of luxury symbolic consumption.

\section{References}

Aaker, J. L., and Lee, A. Y., (2001), “'I' seek pleasures and 'we' avoid pains: The role of self-regulatory goals in information processing and persuasion", Journal of Consumer Research, vol. 28, no. 1, pp. 33-49.

Agarwal, S., and Sikri, S.,(1996), "Country image: consumer evaluation of product category extensions",International Marketing Review, vol. 13, no. 4, pp. 23-39. 
Ahmed, S. A., and d'Astous, A., (1995), "Comparison of country of origin effects on household and organizational buyers' product perceptions", European Journal of Marketing, vol. 29, no. 3, pp. 35-51.

Ahmed, S. A., and d'Astous, A., (1996), "Country-of-origin and brand effects: a multidimensional and multi-attribute study", Journal of International Consumer Marketing, vol. 9, no. 2, pp. 93-115.

Ahmed, S. A., d'Astous, A., and Eljabri, J.,(2002), "The impact of technological complexity on consumers' perceptions of products made in highly and newly industrialised countries", International Marketing Review, vol. 4, pp. 387-407.

Aiello, G., Donvito, R., Godey, B., Pederzoli, D., Wiedmann, K. P., Hennigs, N., and Ivanovna, S. I., (2009), "An international perspective on luxury brand and country-oforigin effect", Journal of Brand Management, vol. 16, no. 5-6, pp. 323-337.

Askegaard, S., and Ger, G., (1998), "Product-country images: towards a contextualized approach", E-European Advances in Consumer Research, vol. 3.

BAIN \& COMPANY. China Luxury consumption in 2013, 2013.12.

Batra, R., Ramaswamy, V., Alden, D. L., Steenkamp, J.-E. B. M., and Ramachander, S., (2000), "Effects of brand local and nonlocal origin on consumer attitudes in developing countries", Journal of Consumer Psychology, vol. 9, no. 2, pp. 83-95.

Bauer, Hans H. Udo Klein-Bolting, Tharek Murad Aga, Bjorn Sander, Alexandra Valtin. Brand equity drivers model. BBDO reports, Germany, 2004, 3

Bearden, W. O.,Etzel, M. J.,(1982), "Reference group influence on product and brand purchase decisions",Journal of Consumer Research, vol. 9, pp. 183-194.

Belen del Rio, A., Vazquez, R., and Iglesias, V., (2001), "The effects of brand associations on consumer response", Journal of Consumer Marketing, vol. 18, pp. 410-425.

Belk, R. W., (1995), "A hyperreality and globalization: Culture in the age of Ronald McDonald", Journal of International Consumer Marketing, vol. 8, no. 3/4, pp. 477490.

Belk, R. W.,(1988), "Possessions and the extended self”, Journal of Consumer Research, vol. 15, pp.139-168.

Belk, R., Mayer, R., andBahn, K.,(1982), "The eye of the beholder: individual differences in perceptions of consumption symbolism", Advances in Consumer Research, vol. 9, no. 1,pp. 523-530.

Belk, R., Mayer, R. N., and Driscoll, A.,(1984), “Children's recognition of consumption symbolism in Children's products", Journal of Consumer Research, vol. 10, pp. 386397.

Biel, A.L., (1992), "How brand image drives brand equity?", Journal of Advertising Research, vol. 32, no. 6, pp. 6-12.

Bilkey, W. J., Nes, E.,(1982), "Country-of-origin effects on product evaluations", Journal of International Business Studies, pp. 89-99

Blair, M. E., and Innis, D. E., (1996), "The effects of product knowledge on the evaluation of warranted brands", Psychology \& Marketing, vol. 13, no. 5, pp. 445-456.

Botschen, G., \& Hemettsberger, A., (1998), "Diagnosing means-end structures to determine the degree of potential marketing program standardization", Journal of Business Research, vol. 42, pp. 151-159.

Bourne, F. S., (1956), "Group influence in marketing and public relations",Some Applications of Behavioral Research, pp. 207-255

Brucks, M., Zeithaml, V. A., and Naylor, G., (2000), "Price and brand name as indicators of quality dimensions for consumer durables", Academy of Marketing Science Journal, vol. 28, no. 3, pp. 359-374.

Chao, P., and Rajendran, K. N., (1993), "Consumer profiles and perceptions: country-oforigin effects", International Marketing Review, vol. 10, no. 2.

Chao, P., (1993), "Partitioning country-of-origin effects: consumer evaluations", Journal of International Business Studies, vol. 24, no. 2, pp. 291-306.

Chattalas, M., Kramer, T., and Takada, H., (2008), "The impact of national stereotypes on the country of origin effect: A conceptual framework", International Marketing Review, 
vol. 25 , no. 1 , pp. $54-74$.

Chen, H. L., (2004), "Testing the role of country of origin in consumer adoption of new products", International advances in economic research, vol. 10, no. 3, pp. 245-245.

Childers, T. L., and Rao, A. R.,(1992), "The Influence of Familial and Peer-based Reference Groups on Consumer Decisions", Journal of Consumer Research, vol. 19, pp. 198-211.

De Chernatony,and L., Riley, F. D. O., (1998), "Expert practitioners' views on roles of brands: implications for marketing communications", Journal of Marketing Communications, vol. 4, no. 2, pp. 87-100.

Dichter, E.,(1962), “The world customer”, The International Executive, vol. 4, no. 4, pp. 2527.

Dornoff, R. J.,Tankersley,C. B.,and White, G. P., (1974), "Consumers' perceptions of imports", Akron Business and Economic Review, vol. 5, no. 2, pp. 26-29.

Dube, L., and Menon, K., (2000), "Multiple roles of consumption emotions in post-purchase satisfaction with extended service transactions", International Journal of Service Industry Management, vol. 11, no. 3, pp. 287-304.

Eng, T. Y., and Bogaert, J.,(2010), "Psychological and cultural insights into consumption of luxury Western brands in India", Journal of Customer Behavior, vol. 9, no. 1, pp. 5575.

Erickson, G.M., Johansson, J.K., and Chao, P., (1984), "Image variables in multi-attribute product evaluations: country-of-origin effects", Journal of Consumer Research, vol. 11, no. 2, pp. 694-699.

Essoussi, L. H., and Merunka, D., (2007), "Consumers' product evaluations in emerging markets: Does country of design, country of manufacture, or brand image matter?", International Marketing Review, vol. 4, pp. 409-426.

Fischer, E.,(2000), "Consuming contemporaneous discourses: A postmodern analysis of food advertisements targeted toward women", Advances in Consumer Research, vol. 27, pp. 288-294.

Forehand, M. R., Deshpande, R., and Reed, A. II.,(2002), "Identity Salience and the Influence of Activation of the Social Self-Schema on Advertising Response", Journal of Applied Psychology, vol. 87, no. 6, pp. 1086-1099.

Fornell, C., and Larcker, D. F., (1981), "Structural Equation Models with Unobservable Variables and Measurement Error: Algebra and Statistics", Journal of Marketing Research, vol. 18, no. 3, pp.382-388.

Fournier, S.,(1998), "Consumers and their brands: Developing relationship theory in consumer research", Journal of Consumer Research, vol. 24, no. 4,pp. 343-353.

Frijda, N. H.,(1988), "The laws of emotion", American Psychologist, vol. 43, no. 5, pp. 348358.

Gaedeke, R.,(1973), "Consumer attitudes toward products made in developing countries", Journal of Retailing, vol. 49, pp. 13-24.

Gerstner, E.,(1985), “Do high price signal higher quality?"Journal of marketing research, vol. 22, pp. 209-215.

Godey, B., Pederzoli, D., Aiello, G., et al.,(2012), "Brand and country-of-origin effect on consumers' decision to purchase luxury products", Journal of Business Research, vol.65, no. 10, pp. 1461-1470.

Haire, M.,(1950), "Projective techniques in marketing research", Journal of Marketing, vol. 14, no. 5,pp. 649-656

Han, C. M.,(1989), “Country image: halo or summary construct?", Journal of Marketing Research, vol. 26, no. 2, pp. 222-229.

Han, C. M., and Terpstra, V., (1988), "Country-of-origin effects for uni-national and binational products", Journal of International Business Studies, vol. 19, no. 2, pp. 235255.

Han, Y. J., Nunes, J. C., and Drèze, X.,(2010), "Signaling Status with Luxury Goods: The Role of Brand Prominence", Journal of Marketing, vol. 74, no. 4, pp.15-30.

Häubl, G., andElrod, T.,(1999), "The impact of congruity between brand name and country of production on consumers' product quality judgments", International Journal of 
Research in Marketing, vol. 16, no. 3,pp. 199-215.

Higgins, E. T., Roney, C. J.R.,Crowe, E., and Hymes, C., (1994), "Ideal Versus Ought Predilections for Approach and Avoidance: Distinct Self-Regulatory Systems", Journal of Personality and Social Psychology, vol. 66, pp.276-286.

Higgins, E. T., (1998), "Promotion and Prevention: Regulatory Focus as a Motivational Principle,"in Zanna, M. P. (Ed.), Advances in experimental social psychology, vol. 30, San Diego: Academic Press, pp. 1-46.

Hogg, M. K., Cox, A. J., and Keeling, K.,(2000), "The impact of self-monitoring on image congruence and product/brand evaluation", European Journal of Marketing, vol. 34, no. 5/6, pp. 641-667.

Holman, R. H., (1980), “Apparel as Communication" in Hirschman, E., and Holbrook, M. (Eds.), Symbolic Consumption Behavior, Proceedings of the Conference on Consumer Esthetics and Symbolic Consumption. New York, pp. 7-12.

Hong, S.T., and Wyer, R.S. Jr.,(1989), "Effects of country-of-origin and product-attribute information on product evaluation: an information processing perspective", Journal of Consumer Research, vol. 16, no. 9, pp. 175-187.

Johansson, J.K., Douglas, S.P., and Nonaka, I., (1985), "Assessing the impact of country of origin on product evaluations: a new methodological perspective", Journal of Marketing Research, vol. 22, no. 9, pp. 388-396.

Keller, K. L.,(1993), "Conceptualizing, Measuring, and Managing Customer- Based Brand Equity", Journal of Marking, vol. 57, no. 1, pp. 1-22.

Keller,P.A., Lipkus, A., and Rimer, B. K.,(2003), "Affect, framing and persuasion”, Journal of Marketing Research, vol. 40, no. 1, pp. 54-64.

Khachaturian, J. L., and Morganosky, M. A., (1990), "Quality Perceptions by Country of origin", International Journal of Retail \& Distribution Management, vol. 18, no. 5, pp. 21-30.

Khan, U., and Dhar, R., (2006), "Licensing Effect in Consumer Choice", Journal of Marketing Research, vol. 43, no. 2, pp. 259-266.

Kinra, N., (2006), "The effect of country of origin on foreign brand names in the Indian market", Marketing Intelligence and Planning, vol. 24, no. 1, pp. 15-30.

Krishnan, H. S.,(1996), "Characteristics of memory associations: A consumer-based brand equity perspective", International Journal of research in Marketing, vol. 13, no. 4, pp. 389-405.

Kleine III, R. E., Kleine, S. S., and Kernan, J. B.,(1993), "Mundane consumption and the self: A social-identity perspective", Journal of Consumer Psychology, vol. 2, no. 3, pp. 209235.

Laroche, M., Papadopoulos, N., Heslop, L. A., and Mourali. M., (2005), "The influence of country image structure on consumer evaluations of foreign products", International Marketing Review, vol. 22, no. 1, pp. 96-115.

Lee, A. Y., and Aaker, J. L., (2004), "Bringing the frame into focus: the influence of regulatory fit on processing fluency and persuasion", Journal of Personality and Social Psychology, vol. 86, no. 2, pp. 205-218.

Lee, D., and Ganesh, G., (1999), "Effects of partitioned country image in the context of brand image and familiarity", International Marketing Review, vol. 16, no. 1, pp. 18-41.

Lefko.-Hagius, R., and Mason, C.H., (1993), "Characteristic, beneficial, and image attributes in consumer judgments of similarity and preference", Journal of Consumer Research, vol. 20, pp. 100-110.

Leibenstein, H., (1950), "Bandwagon, snob, and Veblen effects in the theory of consumers' demand", The Quarterly Journal of Economics, vol. 64, pp. 183-207.

Leigh, J. H., and Gabel, T. G., (1992), "Symbolic Interactionism: its effects on consumer behavior and implications for marketing strategy", Journal of Consumer Marketing, vol. 9, no. 1, pp. 27-38.

Lillis, C. M., and Narayana, C. L.,(1974), "Analysis of "made in" product images-An exploratory study", Journal of International Business Studies, pp. 119-127.

Lim, K., and O'Cass, A.,(2001), "Consumer brand classifications: an assessment of culture 
of-origin versus country-of-origin",Journal of Product and Brand Management, vol. 10 , no. 2, pp. 120-36.

Lin C.H., and Kao, D. T.,(2004), "The impacts of country-of-origin on brand equity", Journal of American Academy of Business, vol. 5, no. 1/2, pp. 37-40.

Lockwood, P., Jordan, C. H., and Kunda, Z.,(2002), "Motivation by Positive or Negative Role Models: Regulatory Focus Determines Who Will Best Inspire Us", Journal of Personality and Social Psychology, vol. 83, no. 4, pp. 854-864.

Maldonado, R., andTansuhaj, P.,(1999), "Transition Challenges in Consumer Acculturation: Role Destabilization and Changes in Symbolic Consumption", Advances in Consumer Research, vol. 26, no. 1, pp. 134-140.

Martin, I.M., and Eroglu, S., (1993), "Measuring a Multi-dimensional construct: country image", Journal of Business Research, vol. 28, pp. 191-210.

Martín, O. M., and Cerviño, J.,(2011), "Towards an integrative framework of brand country of origin recognition determinants: A cross-classified hierarchical model", International Marketing Review, vol. 28, no. 6, pp. 530 -558.

McKinsey, Report on Emerging China luxury market, 2011,4.

Mittal, B., Ratchford, B., and Prabhakar, P., (1990), "Functional and expressive attributes as determinants of brand-attitude", Research in Marketing, vol. 10, pp. 135-155.

Nagashima, A.,(1977), “A comparative 'made in' product image survey among Japanese businessmen", Journal of Marketing,vol. 41, no. 3, pp. 95-100.

Nagashima, A.,(1970), "A comparison of Japanses and U.S. attitudes toward foreign products", Journal of Marketing,vol. 34(January), pp. 68-74.

Narayana, C. L.,(1981), "Aggregate images of American and Japanese products: implications on international marketing", Columbia Journal of World Business, vol. 16 (summer),pp. 31-35.

Nebenzahl,I.D.,Jaffe,E.D., and Usunier, J.-C., (2003), "Personifying country of origin research", Management International Review, vol. 43, no. 4, pp. 383-406.

Otnes, C., Lowrey, T. M., and Shrum, L. J.,(1997), "Toward an understanding of consumer ambivalence", Journal of Consumer Research, vol. 24, no. 1, pp. 80-93.

Papadopoulas, N., Heslop, L.A., and Beracs, J.,(1990), "National stereotypes and product evaluations in a socialist country", International Marketing Review, vol. 7, pp. 32-47.

Parameswaran, R.,and Pisharodi, R. M.,(1994), "Facets of Country of Origin Image: An Empirical Assessment", Journal of Advertising, vol. 23, no. 1, pp. 43-56.

Peabody, D., (1985), National Characteristics, Cambridge: Cambridge University Press.

Pereira, A., Hsu, C. C.,and Kundu, S. K.,(2005), "Country-of-origin image: measurement and cross-national testing", Journal of Business Research, vol. 58, no. 1, pp. 103-106.

Pham, M. T., and Avent, T.,(2004), "Ideals and oughts and the reliance on affect versus substance in persuasion", Journal of Consumer Research, vol. 3, pp. 503-518.

Phau, I., and Leng, Y. S.,(2008), "Attitudes toward domestic and foreign luxury brand apparel: A comparison between status and non status seeking teenagers", Journal of Fashion Marketing and Management, vol. 12, no. 1,pp. 68-89.

Phau.I., and Prendergast, G.,(2000), "Conceptualizing the country of origin of brand", Journal of Marketing Communications, vol. 6, no. 3, pp. 159-170.

Phau, I.,and Prendergast, G., (1998), "Contemporary perspectives of the Asian conspicuous consumer: an agenda of research propositions" In Business and Economics Society International Conference 1998, Rome, July, pp. 17-21.

Piron, F., (2000), "Consumers' perceptions of the country-of-origin effect on purchasing intentions of (in) conspicuous products", Journal of Consumer Marketing, vol. 17, no. 4, pp. 308-321.

Quester, P. G., and Smart, J., (1998), "The influence of consumption situation and product involvement over consumers' use of product attribute",Journal of Consumer Marketing, vol. 15 , no. 3, pp. $220-238$.

Reierson, C.,(1966), "Are foreign products seen as national stereotypes?",Journal of Retailing, vol. 42, pp. 33-40.

Reitzle, W.,(2003), Luxury brings fortune, (Feng Liu, Trans.), Beijing: Citic Press. 
Richins, M. L.,(1994), "Special possessions and the expression of material values", Journal of Consumer Research, vol. 21, pp. 522-533.

Rogers, C. R., (1961), On becoming a person,Boston: Houghton Mifflin.

Roth, M. S., and Romeo, J.B.,(1992), "Matching product and country image perceptions: a framework for managing country of origin effects", Journal of International Business Studies, vol. 23, no. 3, pp. 477-497.

Ruder Finn, Albatross Global Solutions, Report on China luxury consumption from 2011 to 2012, 2011.11.

Ruder Finn, Luxury consumption in 2014, 2013.12.

Ruvio, A., Shoham, A., and Makovec Brencic, M., (2008), "Consumers' need for uniqueness: short-form scale development and cross-cultural validation", International Marketing Review, vol. 25, no. 1, pp. 33-53.

Samiee, S., Shimp, T. A., and Sharma, S.,(2005), "Brand origin recognition accuracy: its antecedents and consumers' cognitive limitations", Journal of International Business Studies, vol. 36, pp. 379-397.

Schau, H. J., and Gilly, M. C.,(2003), "We are what we post? Self - presentation in personal web space", Journal of Consumer Research, vol. 30, no. 3, pp. 385-404.

Schau, H. J., and Russell, C. A.,(2005), "Me, my self, and my brands", Advances in Consumer Research, vol. 32, no. 1, pp. 335-338.

Schooler, R.,(1971), "Bias Phenomena attendant to the marketing of foreign goods in the US", Journal of International Business Studies, vol. 2, no. 1, pp. 71-80.

Schooler, R.D., (1965), "Product bias in central American common market", Journal of Marketing Research, vol. 2, no. 4,pp. 394-397.

Sengupta, J.,and Zhou, R.,(2007), "Understanding Impulsive Eaters' Choice Behaviors: The Motivational Influences of Regulatory Focus", Journal of Marketing Research, vol. 44, no. 2, pp. 297-308.

Shimp, T. A., and Sharma, S.,(1987), "Consumer ethnocentrism: construction and validation of the CETSCALE", Journal of Marketing Research, vol. 24, no. 3, pp. 280-289.

Sundie, J. M., Kenrick, D. T., Griskevicius, V.,Tybur, J. M., Vohs, K. D.,and Beal, D. J., (2011), "Peacocks, Porsches, and Thorstein Veblen:Conspicuous Consumption as a Sexual Signaling System", Journal of Personality and Social Psychology, vol. 100, no. 4, pp. 664-680.

Shuptrine, F.K.,(1975), "On the Validity of using students as subjects in consumer behavior investigations", The Journal of Business, vol. 48, no. 7, pp. 383-390.

Snyder, C. R., and Fromkin, H. L.,(1980), Uniqueness: The human pursuit of difference, New York: Plenum Press.

Snyder, C. R.,(1992), "Product scarcity by need for uniqueness interaction: a consumer catch22 carousel?", Basic and Applied Social Psychology, vol. 13, no. 1, pp. 9-24.

Stayman, D. M., and Deshpande, R., (1989), "Situational Ethnicity and Consumer Behavior",Journal of Consumer Research, vol. 16 (December), pp. 361-371.

Teas, R. K.,and Agarwal, S.,(2000), "The effects of extrinsic product cues on consumers' perceptions of quality, sacrifice, and value", Journal of the Academy of Marketing Science, vol. 28, no. 2, pp. 278-290.

Thakor, M.V., and Kohli, C., (1996), "Brand origin: conceptualisation and review", Journal of Consumer Marketing, vol. 13, no. 3, pp. 27-42.

Tsai, S. P.,(2005), "Utility, cultural symbolism and emotion: A comprehensive model of brand purchase value", International Journal of Research in Marketing, vol. 22, no. 3, pp. 277-291.

Tse, D.K., and Gorn, G.J., (1993), "An experiment on the salience of country of origin in the era of global brands", Journal of International Marketing, vol. 1, no. 1, pp. 57-76.

Van Osselaer, S. M. J., and Janiszewski, C., (2001), "Two ways of learning brand associations", Journal of Consumer Research, vol. 28, no. 2, pp. 202-223.

Verlegh, P. W. J., and Steenkamp, J. B. E. M.,(1999), "A review and meta-analysis of country-of-origin research", Journal of Economic Psychology, vol. 20, no. 5, pp. 521546. 
Vigneron, F., and Johnson, L. W.,(1999), "A Review and a Conceptual Framework of Prestige-Seeking Consumer Behavior”, Academy of Marketing Science Review, vol. 1, pp. 1-15.

Vigneron. F., and Johnson, L. W.,(2004), "Measuring perceptions of brand luxury", Brand management, vol. 11, no. 6, pp. 484-506.

Voase, R.,(2002), "Rediscovering the imagination: Investigating the active and passive visitor in the 21st century", International Journal of Tourism Research, vol. 4, pp. 391-399.

Voltaire 1736 Le mondain, Hubert François Gravelot (ed.) Collection complette des oeuvres de M. de Voltaire: Poésies mêlées, 1771

Voltaire. On luxury. Voltaire Classical corpus. (Yuqing Li,Trans.). Shanghai: Shanghai University Press, 2006, 11

Wilcox, K., Kim, H.M., and Sen, S., (2009), "Why Do Consumers Buy Counterfeit Luxury Brands?",Journal of Marketing Research, vol. 46, no. 2, pp. 247-259.

Wong, N. Y., and Ahuvia, A. C., (1998), "Personal Taste and Family Face: Luxury Consumption in Confucian and Western Societies", Psychology \& Marketing, vol. 15, no. 5, pp. 423-441.

Zhu, R., Meyers-Levy, J.,(2007), "Exploring the Cognitive Mechanism that Underlies Regulatory Focus Effects", Journal of Consumer Research, vol. 34, no. 1, pp. 89-96. 